\title{
Scientific and Traditional Knowledge in Odontology
}

\author{
María del Pilar Adriano Anaya1, Tomás Caudillo Joya', Nicolás Malinowski², \\ Pilar Alejandra Caudillo Adriano ${ }^{3}$ \\ ${ }^{1}$ School of Continuing Studies, UNAM, Zaragoza, México \\ ${ }^{2}$ Cuautitlán Izcalli University, Campus Chopos, México \\ ${ }^{3}$ Metropolitan University Autonomy, Xochimilco, México \\ Email: adriano124@hotmail.com
}

Received 25 May 2014; revised 10 July 2014; accepted 26 July 2014

Copyright (C) 2014 by authors and Scientific Research Publishing Inc.

This work is licensed under the Creative Commons Attribution International License (CC BY).

http://creativecommons.org/licenses/by/4.0/

c) (i) Open Access

\begin{abstract}
Introduction: We present the results of scientific and traditional knowledge, which were performed on students attending the School of Dental Surgery at the Faculty of Higher Studies Zaragoza UNAM and parents in the Milpa Alta policy delegation of the Federal District with the purpose to articulate such knowledge for planning oral health programs where the protection and promotion of oral health are prioritized. Method: This study was qualitative and quantitative, and 413 students of the career Dentist Faculty of Higher Studies Zaragoza UNAM and 2100 parents of twelve elementary school of the Milpa Alta delegation participated. Results: One of the results was that almost a third (28\%) of the students go to the dentist only when they need to, however $40 \%$ of parents said they go to consultation only when they start to experience pain. Conclusion: It is important to articulate scientific knowledge with the traditional and famed in Odontology, for the operation alization of health programs attached to particular contexts where all stakeholders are involved to prevent oral problems.
\end{abstract}

\section{Keywords}

Knowledge, Empowerment, Health Disease Process, Tooth Decay, Promotion

\section{Introduction}

The notions of knowledge and understanding, scope and functions have changed along the history [1]. This is demonstrated by the interpretation of the various phenomena that come up from the origin of man prevailed where the magic-religious determination and generating proposals for their solution [2]. 
During the Middle Age, esoteric and spiritualized knowledge prevailed, that is to say, it was integrated notions close near to religion. The transcendent and spiritualized knowledge was considered superior to any other, for its quality of direct revelation from a legitimate and legitimizing external source: the Creator, since the exclusion of knowledge becomes one of the characteristics of Western culture [1].

The rupture between traditional and spiritualized knowledge with scientific ones rests with the new forms of life in the seventeenth century with René Descartes [3] and legitimization of scientific knowledge from Reason.

In the twentieth century the trend of knowledge exclusion is legitimized by the ideal of objectivity and they are marginalized including traditional or folk. In recent years it has been developing a whole theoretical proposal which aims at the integration of knowledge in which a correlation of these values and the inclusion of there.

Science has become contested terrain both epistemic and political; there has been a lot of "colonial" campaigns who have tried to tell the truth about the health and illness of individuals and more recently of collectivity from different ideologies and domains of scientificity. However, with the crisis of modernity, we have begun to understand (or rather, we remembered) that health is not an object that can be confined to a single discipline and that the fragmentary logic of modern science often put us away from any possibility to understand health in its inherent complexity [4].

According to Nicolas Malinowski [5], science and knowledge production are strongly marked by vertical mechanisms of thought; scientist posture is characterized by a marked self-sufficiency which denigrates nonacademic views, considered irrational and ignorant, this position of reject of nonscientific knowledge is shared by the public authorities within a technocratic perspective of his work. The knowledge is revealed to be as legitimate and valid as scientific ones and should be considered as complementary.

Carlos Delgado [6] considers that the dialogue between knowledge is necessary to reorganize our paradigm, by changing mindsets, behaviors and ways of thinking and working.

"Although emergencies of the present favor consensus about dialogue of knowledge, they are not sufficient, neither the willingness of the partners, or the existence of a rational basis for a thoughtful dialogue, consensus and intention to overcome the domination relations in a common effort to find solutions to urgent, they are not sufficient to ensure by themselves an effective and fruitful dialogue. Dialogue does not mean only knowledge or fundamentally, grouping, sharing and integration of knowledge. Dialogue is not only required, to solve urgent problems. It is required to reorganize knowledge, produce by changing mindsets, behaviors, ways of thinking and working. That is the significance of the dialogue of knowledge understood in the context of the problem of the organization of knowledge. In practical terms, this means a vital challenge as we face our own horizons of understanding and action."

This represents a challenge as it necessitates we face our own horizons of understanding and action, we need to think the bases supporting the way of thinking that has contributed to the problems we want to solve today using integrative thinking.

The dialogue is just meeting, recognition of the others, knowing with knowledge and understanding that communities are also builders of knowledge. It goes beyond mere classification in a common or scientific and popular knowledge, holding inequality. It is the statement and claim that when we meet, both become knowledge builders [7].

Knowledge dialogue in Odontology represents a very intellectual challenge to be understood as a process of communication between stakeholders with scientific knowledge and social actors with traditional or popular ones, to make possible an articulation between both types of knowledge, with respect and mutual transformation.

With dialogue we recognize the other as an actor and respect his ability to build knowledge [8].

Knowledge dialogue requires that the educator has a permanent reflective attitude to understand his role in this web of stresses and strains. As part of this reflective process come the dialogic considerations to have on humans, culture and scientific knowledge [9]. Education is an act of love, and therefore, an act of courage, dialogue cannot be afraid by debate; does not impose, does not dictate ideas, does not work on the learner, but works with him [10].

We must consider knowledge dialogue in odontology as a part of health promotion. Let's understand a complex process with respect to culture, values, symbols, traditions, where there is an empowerment of social actors on the understanding knowledge of the determinants of oral health and disease [11] [12]. The odontologist must not intervene in communities imposing his knowledge, but rather promote dialogue with the population under study, listen, respect and recognize the population, who interpret and express their meanings about dental problems and present how to resolve their problems, since they are owners of their own knowledge. 
The health-disease process from an Epidemiological point of view [13] [14] is the result of a set of determinants that work in a concrete society and produce in different groups apparition of risks or characteristic potentials, which in turn are manifested in the form of profiles or patterns of illness or health, of which oral health is an integral part.

The dialogue of knowledge on oral health-disease process is not intended to make the other think or act in a certain way, but it is based on respect and strengthening the autonomy. It requires respect for differences under a basic consensus: the ability to express freely and without coercion positions, interests, concerns and needs. We must leave behind any dogmatic or paternalistic position and understand that each person is responsible for their own growth and their own actions, because it assumed the other as responsible and free. This involves recognizing the other as an individual, as a person with skills to build their own vision and act with discretion, and as one who finally makes decisions considering its socio-economic and cultural circumstances and personal characteristics [15].

In studies on the perception that society has on their health and disease, it is important to consider the proposal of Mechanic on the notion of "acting against the disease" which is useful to observe differentially in as symptoms are perceived and evaluated and how different people act or fail to act. Individuals are able to give meaning and interpret their circumstances according to the time and situation in which they are located [15].

This point will enable us to understand the way individuals interpret health-mouth disease and the actions to implement in order to change or transform it.

From the qualitative research, the epistemic reality requires a knowing subject, influenced by culture and individual social relations that make epistemic reality depends for its definition, comprehension and analysis, knowledge of the ways of perceiving, thinking, feeling and acting, that are specific to those cognizant. It is assumed in this paradigm that knowledge is a shared construction from the interaction between the researcher and the researched, in which the values mediate or influence the generation of knowledge [16].

Within these actions we find the curative, in which intervening institutional, health care, private and traditional work, preventive type, are focused on the environment or the individual and the promotion of health which gives priority to the person, the group or society [17].

Among the studies that attempt to extend the explanatory context of the problems of oral health-disease population we can quote one made in Colombia [18], with mothers in primary schools about: Oral health, a question of culture? Where addresses this issue from a sociocultural perspective, describes the importance that exists for the different stakeholders on the interpretation of dental treatments that are considered beneficial, the origin of oral problems and institutional responses to address these. We conclude that the perception of oral health is directly related to the culture to which the social actor belongs and resolve their oral health problems in the situation where they are located.

Another ethnographic study that makes a significant relationship between oral health and social and cultural behaviors in the family is held in Venezuela [19] in the year 2006: A study of the habits that influence oral health disease process in a group of mothers from the community of San Isidro was performed. The results of this research were identified by dental situations problematized by mothers that have meaning for the family, the authors involved in the search for solutions, all confined in the context of everyday family life and the relationships that exist with the social environment.

A 1990 study in the city of Nezahualcoyotl [20], about teacher's knowledge in primary and secondary schools as well as parents of the same, teachers have information on the etiology of dental caries and the impact on the heart valves, also say that they can potentially cause gastrointestinal problems in individuals toothless due to poor chewing. Relating dental caries and periodontal disease to the impact the rest of the parent body consider that these cause gastrointestinal diseases and infections. Preventive methods used by parents and teachers are brush and toothpaste as well as the burnt tortilla and ash from the stove.

Surely the knowledge dialogue and his articulation is urging in the dental profession, the training of human resources, knowledge production and production services, to expand the explanatory frameworks of oral health disease process where we find problems high prevalence such as dental caries, periodontal disease and malocclusion showing increasing needs in the population, the production of services to institutional and private level cannot solve and lore learned from generation to generation, or by common sense whenever you are solving more oral problems.

This study is located within the element of knowledge production that has been considered in Latin America, as an active process, arduous, difficult to develop, understand, conceptualize and therefore often undertaken, and 
others only in the theory.

\section{Method}

This study is qualitative-quantitative about the scientific and traditional knowledge that has population study regarding oral health and disease, habits for control, prevention methods that allow us to highlight these services using for resolution. With a convenience sample of 2100 parents of twelve elementary 175 for each of the twelve villages that make up the delegation of Milpa Alta located in the City of Mexico, 2100 in total; and 413 students from the Odontology's Career Faculty of Zaragoza in the UNAM. To carry out this study we meet the parents with whom they talked about the objective of the polland that the results would serve to develop a program specific protection and other promotion of oral health in children, with the aim of reducing dental caries met in $50 \%$ and generate in them a culture of oral health, for which a questionnaire was developed with nine questions, with two of which are open and seven closed, about the cause (knowledge), prevention and service demanded to solve their dental problems. A parent is sent home prior information questionnaire written its objectives and those who responded and were returned with their children to primary formed this sample.

Subsequently students career Dentist FES-Zaragoza, we applied the same questionnaire in their classrooms prior classes explaining its objectives and those it answered voluntarily formed the sample of 413 students from the four years-career.

Regarding to the open questions, responses were concentrated according to integrative concepts and retaining only those with one answer. With regard to closed question, we only recorded only responses with percentages.

\section{Results}

This study involved 413 students in the career of Dental Surgery, 104 from the first year, 105 the second, 103 in third year and 101 in fourth year. And 2100 parents of twelve public elementary schools in the Milpa Alta delegation. Then sequentially we analyze the responses from different audiences to questions.

The first question is: How often you visit a Dentist? 65 students (16\%) responded they go to the dentist once a year, 223 (54\%), of them every six months, 9 (2\%), 116 (28\%) never had gone or only when the need. (Question 1)

\begin{tabular}{|ccc|}
\hline \multicolumn{3}{c}{ Question 1: How often do you visit a dentist? Students answers } \\
\hline Options & No. & $\%$ \\
\hline Once a year & 65 & 15.7 \\
Every six months & 223 & 54.0 \\
Never visited & 9 & 2.2 \\
Only when I need it & 116 & 28.1 \\
Total & 413 & 100 \\
\hline
\end{tabular}

$49 \%$ of parents said go every six months to a year, and $40 \%$ visit it only when you have pain, it is important to note that $4 \%$ of the parents interviewed had never gone to the dentist. (Question 1)

\begin{tabular}{|ccc|}
\hline Question 1: How often do you visit a dentist? Parents answers & \\
\hline Options & No. & $\%$ \\
\hline Once a year & 531 & 25.2 \\
Every six months & 510 & 24.3 \\
Every three months & 153 & 7.3 \\
Never visited & 75 & 3.6 \\
Only when I feel pain & 807 & 38.5 \\
Every two years & 24 & 1.1 \\
Total & 2100 & 100 \\
\hline
\end{tabular}


The second question is about which reasons to visit the dentist: $52 \%$ of students visiting the dentist for review, $28 \%$ only when you have pain and $20 \%$ do it for prevention. (Question 2)

\begin{tabular}{|ccc|}
\hline Question 2: What are the reasons that have visited the Dentist? Students answers \\
\hline Options & No. & $\%$ \\
\hline Review & 215 & 52 \\
Prevention & 81 & 20 \\
Pain & 117 & 28 \\
Total & 413 & 2100 \\
\hline
\end{tabular}

$69 \%$ of parents visit the dentist only for pain, 19\% for revision and 12\% for prevention. (Question 2)

\begin{tabular}{|ccc|}
\hline Question 2: What are the reasons that have visited the Dentist? Parents answers \\
\hline Options & No. & $\%$ \\
\hline Review & 404 & 19 \\
Prevention & 242 & 12 \\
Pain & 1454 & 69 \\
Total & 2100 & 100 \\
\hline
\end{tabular}

In the third question we asked to explain briefly that is tooth decay: there were 26 different options, answers most respondents students are $23.7 \%$ the be explained as a multifactorial disease, $16.5 \%$ as a disease of the teeth, $13.1 \%$ is a bacterial disease, $8.2 \%$ is the process of demineralization of teeth. Among other options. (Question 3)

\begin{tabular}{|c|c|c|}
\hline \multicolumn{3}{|c|}{ Question 3: Briefly explain what is tooth decay Students answers } \\
\hline Options & No. & $\%$ \\
\hline 1.- It is a multifactorial disease & 98 & 23.7 \\
\hline 2.- It is a disease of the teeth & 68 & 16.5 \\
\hline 3.- It is a bacterial disease & 54 & 13.1 \\
\hline 4.- It is the process of demineralization of teeth & 34 & 8.2 \\
\hline 5.- It is the infection of the teeth due to poor hygiene & 23 & 5.6 \\
\hline 6.- It is an abnormality in the tooth causing its rupture & 21 & 5.1 \\
\hline 7.- It is the accumulation of bacteria & 18 & 4.4 \\
\hline 8.- It is a contagious disease & 16 & 3.9 \\
\hline 9.- They are holes in the dentin and enamel & 13 & 3.1 \\
\hline 10.- They are microorganisms damaging to tooth & 10 & 2.4 \\
\hline 11.- It is infection in teeth & 7 & 1.7 \\
\hline 12.- Is the destruction of the tooth structure by bacteria & 7 & 1.7 \\
\hline 13.- They are bacteria that live on the teeth & 6 & 1.5 \\
\hline 14.- It is a pathology that affects the tooth & 5 & 1.2 \\
\hline 15.- They are black spots on teeth & 5 & 1.2 \\
\hline 16.- They are bacteria that calcify on the teeth & 5 & 1.2 \\
\hline
\end{tabular}


Continued

17.- It is a biological process

18.- It is the disease affecting the dentine

19.- It is the condition that causes pain in the teeth

20.- It is something that attacks the teeth

21.- It is the loss of continuity of the enamel

22.- It is the putrefaction of dental cavity

23.- It is a disease that affects the enamel and pulp

24.- It is tooth degradation by bacteria and acids

25.- Is bacterial process that damages the tooth

26.- It is the gradual necrosis of the tooth

With regard to knowledge is very evident the relationship they have with biological factors in the origin of dental caries and a high opinion relates it to $64.1 \%$ bacteria, virus, fungus or disease. The rest of the percentage responses were varied and scattered. (Question 3)

\begin{tabular}{|c|c|c|}
\hline \multicolumn{3}{|c|}{ Question 3: Briefly explain what is tooth decay Parents answers } \\
\hline Responses & No. & $\%$ \\
\hline 1.- Bacteria that destroy teeth & 220 & 11.0 \\
\hline 2.- Rotten teeth & 447 & 21.0 \\
\hline 3.- I don't know & 216 & 10.0 \\
\hline 4.- Black spots on teeth & 228 & 11.0 \\
\hline 5.- Is toothache & 12 & 1.0 \\
\hline 6.- Virus in the teeth & 53 & 2.5 \\
\hline 7.- Tooth destruction & 50 & 2.4 \\
\hline 8.- Tartar on the teeth & 55 & 2.6 \\
\hline 9.- Infection in the teeth & 166 & 7.9 \\
\hline 10.- It is the disease of the teeth & 251 & 12 \\
\hline 11.- Putrid teeth & 23 & 1.1 \\
\hline 12.- They are microbes on teeth & 54 & 2.6 \\
\hline 13.- Worms in the teeth & 7 & 0.3 \\
\hline 14.- It is the poor hygiene of teeth & 128 & 6.1 \\
\hline 15.- Fungi in the teeth & 1 & 0.05 \\
\hline 16.- They are holes in the teeth & 30 & 1.4 \\
\hline 17.- Accumulated food between teeth & 5 & 0.2 \\
\hline 18.- Bugs in the teeth & 13 & 0.6 \\
\hline 19.- Bad teeth & 5 & 0.2 \\
\hline 20.- It is bacterial plaque on teeth & 12 & 0.6 \\
\hline
\end{tabular}


Continued

21.- Is dust teeth

1

0.05

22.- Germs in the teeth

$5 \quad 0.2$

23.- A breakdown of the teeth

2

0.09

24.- It is a degenerative problem of teeth

$2 \quad 0.09$

25.- It is an animal that eats teeth

26.- The teeth lose the layers that from them

27.- Malformed teeth

28.- Sugar affixed to the tooth enamel

29.- Sting by poor brushing

30.- Tooth wastage

31.- Calcification of teeth

32.- Neglect of teeth by poor diet

33.- Ulcers that destroy teeth

34.- Decalcification of teeth

35.- Teeth biting insects

36.- Dirty teeth

37.- Injury to teeth

38.- Corrosion of teeth

39.- Softening of enamel

40.- Bruxism

41.- Tooth deterioration

42.- Weak teeth

43.- Microorganisms in the teeth

10

\begin{tabular}{ccc} 
& 1 & 0.05 \\
& 8 & 0.4 \\
2 & 0.09 \\
& 2 & 0.5 \\
10 & 0.09 \\
13 & 0.6 \\
1 & 0.05 \\
11 & 0.5 \\
5 & 0.2 \\
1 & 0.05 \\
2 & 0.09 \\
4 & 0.2 \\
Total & 12 & 0.6 \\
1 & 0.09 \\
& 5 & 0.2 \\
2100 & 100 \\
\hline
\end{tabular}

In the fourth question we asked for what reasons they consider tooth decay appears: 191 students answered that poor hygiene, 32 multi-causal, 29 poor hygiene and diet, 23 accumulation of bacteria, 15 because of sugars and other factors. (Question 4)

\begin{tabular}{lcc}
\hline \multicolumn{2}{c}{ Question 4: On what grounds do you consider tooth decay occurs? Students answers } \\
\hline \\
\multicolumn{1}{l}{ Options } & No. & $\%$ \\
\hline 1.- Poor hygiene & 191 & 46.2 \\
2.- Multi-causal factors & 32 & 7.7 \\
3.- Poor hygiene and food & 29 & 7.0 \\
4.- Sweets and poor hygiene & 25 & 6.1 \\
5.- Accumulation of bacteria & 23 & 5.6 \\
6.- Intake of sugars & 15 & 3.6 \\
7.- Bad brushed & 15 & 3.6 \\
\hline
\end{tabular}


Continued

\begin{tabular}{lll}
\hline 8.- Bacteria and bad hygiene & 12 & 2.9 \\
9.- PH and poor hygiene & 8 & 1.9 \\
10.- Plaque accumulation & 8 & 1.9 \\
11.- Acid accumulation & 7 & 1.7 \\
12.- Poor hygiene and plaque accumulation & 6 & 1.5 \\
13.- Intake of sweets & 6 & 1.5 \\
14.- Because of streptococcus & 6 & 1.5 \\
15.- Poor hygiene and education & 6 & 1.5 \\
16.- Genetics and poor hygiene & 5 & 1.2 \\
17.- Poor nutrition & 4 & 1.0 \\
18.- Because of enamel wear & 3 & 0.7 \\
19.- Bacteria and acids & 3 & 0.7 \\
20.- Tooth demineralisation & 3 & 0.7 \\
21.- Insufficient brushing teeth & 2 & 0.5 \\
22.- Because of anatomy & 2 & 0.2 \\
23.- Poor hygiene and stress & 1 & 0.2 \\
24.- Because of mineral salts in the tooth & 1 & 0.2 \\
25.- Microorganisms & 1 & 0.2
\end{tabular}

$80 \%$ of this population reported that tooth decay is caused by poor hygiene and the remaining $20 \%$ of your answers are scattered. (Question 4)

\begin{tabular}{|ccc}
\hline Question 4: On what grounds do you consider tooth decay occurs? Parents answers & \\
\hline Category & No. & $\%$ \\
\hline Poor hygiene & 812 & 39.0 \\
Not brushing teeth & 646 & 31.0 \\
By eating sweet & 305 & 14.0 \\
For lack of brushing & 117 & 5.6 \\
Slight cleaning & 85 & 4.0 \\
Junk food & 47 & 1.4 \\
Don't know & 29 & 0.7 \\
For lack of calcium & 2.2 \\
By not going to the dentist & 14 & 0.6 \\
Bad brushing & 12 & 0.4 \\
Careless & 8 & 0.3 \\
Presence of plaque & 7 & 0.1 \\
Acid in the mouth & 3 & 0.1 \\
\hline
\end{tabular}




\begin{tabular}{ccc} 
Continued & & \\
\hline By taking medication & 3 & 0.1 \\
Bad habits & 3 & 0.1 \\
Accumulation of bacteria & 1 & 0.04 \\
Living like pigs & 1 & 0.04 \\
Diseases & 2 & 0.1 \\
Bad genetics & 1 & 0.04 \\
For complex chemical reactions & 1 & 0.04 \\
Total & 2100 & 100 \\
\hline
\end{tabular}

When asked the students in the question five if in their family all the members had a toothbrush, 94\% (388) said yes, $0.7 \%$ (3) there was only a toothbrush for the whole family, and $1.2 \%$ (5), said that not all the family had brush, $2.2 \%$ (9), only father had brush and 1.9\% (8), only mom and dad have a toothbrush and the rest of the family does not. (Question 5)

\begin{tabular}{ccc}
\hline Question 5: All family members have toothbrush for personal use? Students answers \\
\hline Options & No. & $\%$ \\
\hline Yes & 388 & 94 \\
There is a toothbrush for the whole family & 3 & 0.7 \\
Do not have toothbrush & 5 & 1.2 \\
Only dad has & 9 & 2.2 \\
Only mum and dad has & 8 & 1.9 \\
Total & 413 & 2100 \\
\hline
\end{tabular}

Simultaneously in the case of parental responses are consistent: $87 \%$ of this population has toothbrush, $7 \%$ said they have a toothbrush for the entire family and 6\% do not have. (Question 5)

\begin{tabular}{ccc}
\hline Question 5: All family members have toothbrush for personal use? Parents answers \\
\hline Options & No. & $\%$ \\
\hline $\mathrm{Si}$ & 1827 & 87 \\
There is one toothbrush for all the family & 147 & 7 \\
Do not have toothbrush & 126 & 6 \\
Total & 2100 & 100 \\
\hline
\end{tabular}

Question 6 asks: How often do you change your toothbrush?

310 (75\%) students answered that they do it every three months, 68 (16.5\%) answered they change it when is no longer useful, and 35 (8.5\%) of them changes it once a year. (Question 6)

\begin{tabular}{ccc}
\hline Question 6: How often do you change your toothbrush? Students answers \\
\hline Options & No. & $\%$ \\
\hline Every three months & 310 & 75 \\
Once a year & 35 & 9 \\
Cuandoya no sirve & 68 & 16 \\
Total & 413 & 100 \\
\hline
\end{tabular}


1149 parents (55\%) claimed to change toothbrush every three months, 405 (19\%) every six months, 253 (12\%) when bristles are damaged, 275 (13\%) once a year, and 18 of them (1\%) never changed it. (Question 6)

\begin{tabular}{ccc}
\hline Question 6: How often do you change your toothbrush? Parents answers \\
\hline Options & No. & $\%$ \\
\hline Every three months & 1149 & 55 \\
Once a year & 275 & 13 \\
Every six months & 405 & 19 \\
When bristles are damaged & 253 & 12 \\
Never changed it & 18 & 1 \\
Total & 2100 & 100 \\
\hline
\end{tabular}

Question seven asks: When you consult a dentist, to which institution do you go? 333 (80.6) students go to private practice, 31 (7.5\%) the Mexican Social Security Institute (IMSS ${ }^{1}$ ), 19 (4.6\%) clinics of the University, $10(2.4 \%)$ to the Health Center 7 (1.7) to the Institute for Social Security and Services for State Workers (ISSSTE), 9 (2.2\%) to the Dispensary, 2 (0.5\%), to the quack doctor, y 2 (0.5\%) has never consulted the dentist. (Question 7)

\begin{tabular}{ccc}
\hline Question 7: When you consult a dentist, to which institution do you go? Students answers & \\
\hline Options & No. & $\%$ \\
\hline Private practice & 333 & 81 \\
Mexican Social Security Institute & 31 & 7 \\
Clinics of the University & 19 & 2 \\
Health center & 10 & 2 \\
Dispensary & 7 & 2 \\
Never consulted & 9 & 0.5 \\
Quack doctor & 2 & 2 \\
Total & 2100 & 100 \\
\hline
\end{tabular}

In case of the parents, for the care of their oral health, 136 (6.5\%) attend clinics of the UNAM (National Autonomous University of Mexico), 14 (0.7) to the quack doctor, $16(0.8 \%)$ to the herbalist, 138 to the ISSSTE (6.6\%), 645 (30.7\%) go into private practice, 1099 to the Health center (52\%), 32 (1.5\%) do it with home remedies and 20 go to the IMSS (0.9\%). (Question 7)

\begin{tabular}{ccc}
\hline \multicolumn{2}{c}{ Question 7: When you consult a dentist, to which institution do you go? } & \\
\hline Options & No. & $\%$ \\
\hline Private practice & 645 & 31.0 \\
Mexican Social Security Institute & 20 & 0.9 \\
Clinics of the University & 136 & 6.0 \\
\hline
\end{tabular}

${ }^{1}$ The Mexican Social Security Institute (Spanish: InstitutoMexicano del Seguro Social, IMSS) is a governmental organization that assists public health, pensions and social security in Mexico operating under Secretaría de Salud (Secretariat of Health): http://en.wikipedia.org/wiki/Mexican_Social_Security_Institute 


\begin{tabular}{lcc} 
Continued & & \\
\hline \\
Health center & 1099 & 52.0 \\
Institute for Social Security \& Services for State Workers & 138 & 7.0 \\
Home remedies & 32 & 1.5 \\
Quack doctor & 14 & 0.7 \\
Herborist & 16 & 0.8 \\
Total & 2100 & 100 \\
\hline
\end{tabular}

In the question eight, 214 (52\%) students responded that they brush their teeth in the morning and the night, 176 (43\%) three times a day, 5 (1\%) occasionally, 18 (4\%) on the night, and one $(0.2 \%)$, said brushing teeth in the morning. (Question 8)

\begin{tabular}{ccc}
\hline \multicolumn{2}{c}{ Question 8: How often do you brush? Students answers } \\
\hline Options & No. & $\%$ \\
\hline In the morning and evening & 214 & 52.0 \\
On the night & 18 & 4.0 \\
Three times a day & 176 & 43.0 \\
Occasionally & 5 & 1.0 \\
Total & 413 & 100 \\
\hline
\end{tabular}

673 parents brush teeth on the night, 284 three times a day, 876 occasionally, 120 when they remember and 71 never. (Question 8)

\begin{tabular}{ccc}
\hline \multicolumn{2}{c}{ Question 8: How often do you brush? Parents answers } & \\
\hline Options & No. & $\%$ \\
\hline On the night & 673 & 32.0 \\
Three times a day & 284 & 14.0 \\
Occasionally & 826 & 39.0 \\
When I remember & 126 & 6.0 \\
In the morning & 120 & 6.0 \\
Never & 71 & 3.0 \\
Total & 2100 & 100 \\
\hline
\end{tabular}

401 (97\%) students answered brushing teeth with toothpaste, nine (2\%) with bicarbonate, two (0.5\%) with burnt tortilla, and one (0.2\%) with ash from the stove. (Question 9)

\begin{tabular}{ccc}
\hline Question 9: What do you use in family for brushing your teeth? Students answers \\
\hline Options & No. & $\%$ \\
\hline Tooth paste & 401 & 97.0 \\
Bicarbonate & 9 & 2.0 \\
Burnt tortilla & 2 & 0.5 \\
Ash from the stove & 1 & 0.2 \\
Total & 413 & 100 \\
\hline
\end{tabular}


The same results we found with parents: For brushing teeth, 1988 parents reported using toothpaste, 75 bicarbonates, 19 burnt tortilla and 18 ash from the stove. (Question 9)

\begin{tabular}{ccc}
\hline Question 9: What do you use in family for brushing your teeth? Parents answers \\
\hline Options & No. & $\%$ \\
\hline Tooth paste & 1988 & 97.0 \\
Bicarbonate & 75 & 2.0 \\
Burnt tortilla & 19 & 0.5 \\
Ash from the stove & 18 & 0.5 \\
total & 2100 & 100 \\
\hline
\end{tabular}

\section{Discussion}

Performing a study such as this allows a particular vision of two social actors in this case are students Dentist Career and parents of students from different elementary schools in the Milpa Alta, a problem common is oral health and disease, leads us to start a dialogue of knowledge, a scientific and a popular will undoubtedly be of great use to generate proposals in processing or solution.

The structure and organization of the survey takes as criteria the knowledge that these actors have on causation of oral health problems, habits that have to control them, services that come to your solution. Those results are useful for comparison.

Some questions were closer and others open, such that the first had retained precisely and the second the authenticity of subjective responses.

The way in which the two stakeholders responded on the various actions in which the survey was structured allowed us to observe how each of them has specific cognitive abilities that allow them to build their own vision of oral health problems and act therefore taking into account socio-economic, cultural and personal characteristics circumstances.

Almost a third part (28\%) of the students consults a dentist only when they need it, however $40 \%$ of parents said go to this professional when they feel pain.

The reason for consulting a dentist for $52 \%$ of students is to do it for review, while $69 \%$ of parents do it when they feel pain.

When asked students what is tooth decay, there were 26 different responses, of which 25 are single-cause theory Biological and only one at a multi-causal or ecological. This allows us to observe the hegemony of Biological Paradigm in Human Resources Training in Odontology, not having any response that is linked to the Social History or Integral Paradigm. Regarding the knowledge of parents on this issue, although not expressed with dental technicalities prevails in $100 \%$ of the 43 different answers the biological approach of disease.

With regard to the causes of dental caries in students prevails biological view of illness, because the main cause is poor hygiene; $80 \%$ of parents also report that the cause is poor hygiene.

For oral hygiene $94 \%$ of students answered that all family members have toothbrush, although there were five whose response was negative. $97 \%$ of parents said that everyone in family has dental brush and 62 said no. This is an aspect that we should investigate why not all family members have this tool as necessary to control dental caries.

$75 \%$ of students and nearly $55 \%$ of parents change their toothbrush every three months.

$80 \%$ of students go to their oral care to private practice, while parents $52 \%$ do so to the health center characterized as welfare. We can observe the disparity between the two groups of population for the care of their oral problems.

Regarding the habit of tooth brushing, $42.6 \%$ of students brush your teeth twice a day, morning and night; while parents do occasionally 876. Almost half of the students have good habits to control oral problems. However it is not in the parents so we must work in a systematic way to generate in them a culture of health and in the remaining $50 \%$ of students.

For brushing, the two population groups use essentially toothpaste.

The results of this study show that in relation to the etiology and knowledge of dental caries observation can 
conclude that knowledge of both are very similar.

Regarding hygiene habits students are more aware of their importance to the control of oral problems.

We consider that the students, by the relationship they have with their teachers and classmates, resolve their oral problems in private practice, when parents come primarily institutional and health care system.

Self-formation of knowledge-dialogue — that does not mean becoming an absolute polyglot, but to search dynamics to open oneself to diversity. And this is primarily an attitudinal change-will allow us to reorganize knowledge in odontology, produce by changing mindsets, behaviors and mindsets and collaborate.

\section{Conclusions}

There are few studies that integrate the knowledge the population have on the causes of their health problems and how to solve them and less to articulate scientific knowledge with popular and traditional.

We consider traditional knowledge as important as scientific one for planning and implementation of programs of health promotion, precisely because it is based on different mainstays. The active participation of all stakeholders empowerment is needed for the prevention and resolution of their oral problems.

The microbiologist Louis Pasteur said, in the late nineteenth century, to remove his clothes of citizen before to enter to the laboratory... Intent, perhaps, but at least illusory and revealing certain positivist conception of the role of science as a separate expert from the prosaic considerations of political and social world. Meanwhile, the progress of technocracy in the twentieth century contributed to alienating citizens "secular" from the understanding and the legitimacy to speak on progressively more specialized problems.

The complex proposal, humbly but resolutely, is invited to reintegrate those three dimensions that are inherent in human life as a whole_citizen, individual, scientific_and conceive, as an alternative to linear thinking, perspective of ecology of action to be aware of global-term implications of our daily operations and long. Contemporary debates about cloning, genetically modified organisms, sustainable development show-beyond dental problematic that we show in this article-many concrete manifestations of human issues that cannot be limited to a monopoly of a group of experts.

\section{References}

[1] Delgado Díaz, C.-J. (2007) Hacia un nuevo saber. La bioética en la revolución contemporánea del saber. La Habana: Acuario, 12-14.

[2] Comte, A. (1988) Discours sur l'esprit positif. PUF, Paris.

[3] González, J., Sotolongo, P., Correa, A., Malinowski, N., Rodríguez, L. and Mora, D. (2009) Investigación científica. Un encuentro con el paradigma de la complejidad. Instituto Internacional de Integración, Convenio Andrés Bello (III-CAB), La Paz, Bolivia, 39-41.

[4] Alveiro, D. (2012) La Salud Pública como escenario para el diálogo de saberes. Revista CES Salud Pública Venezuela, 3, 1-3.

[5] Malinowski, N. (2013) Pensamiento Complejo. Editorial Pearson, México, 37.

[6] Delgado, C. (2012) Conocimiento, conocimientos, diálogo de saberes. Cuadernos de Ruth, No. 10, 159-180.

[7] Cordero, X. and Romero, E. (2013) Abordaje comunitario y el Diálogos de saberes. Experiencias desde la educación superior. UBV. Zulia. http://www.saber.ula.vbitstream/123456789/16563/1/ponencia21.pdf

[8] Cordero, X. and Romero, E. (2013) Abordaje comunitario y el diálogo de saberes. Experiencias desde la educación superior. http://www.unich.edu.mx/wpcontent/uploads/2013/09/Art.-Abordaje-comunitario-y-Di\%C3\%A1logo-de-Saberes.pdf

[9] Mariño, G. and Cendales, L. (2004) Educación no formal y educación popular. Federación internacional de Fe y Alegría, Caracas, 7-120.

[10] Freire, P. (2005) La educación como práctica de la libertad. Siglo XXI, México, 29-106.

[11] Caudillo, T., Adriano, P. and Gurrola, B. (2013) Formando promotores de la salud bucal. Facultad de Estudios Superiores Zaragoza, UNAM, México, 8.

[12] (2004) Organización Panamericana de la Salud Promoviendo la salud en las Américas. Boletín Epidemiológico, 25. http://www.paho.org/spanish/dd/ais/be_v25n2-cover.htm

[13] Breilh, J. and Granda, E. (1980) Investigación de la salud en la sociedad. Guía pedagógica sobre un nuevo enfoque del método epidemiológico. Ediciones CEAS, Quito, 57-60.

[14] Caudillo, T. (2013) Comprensión compleja del proceso salud-enfermedad bucal. Tesis Doctoral, Doctorado Pens- 
amiento Complejo, Multiversidad Edgar Morín. México, 13.

[15] Bastidas, M., Pérez, F., Torres, J., Escobar, G., Arango, A. and Peñaranda, F. (2009) El diálogo de saberes como posición humana frente al otro: referente ontológico y pedagógico en la educación para la salud. Investigación Educativa Enfermería, 27, 104-111.

[16] Couto, M. (2008) Estado del arte de la Investigación Cualitativa en los estudios odontológicos. Universidad de Carabobo, Venezuela; ODUS Científica Vol. IX No.1 p. 6.

[17] Adriano, P. (2013) Comprensión compleja del proceso salud-enfermedad bucal. Tesis Doctoral, Doctorado Pensamiento Complejo, Multiversidad Edgar Morín, México, 30-33.

[18] Díaz, P. (2013) La salud oral, “cuestión de cultura” Departamento de Salud Pública. Facultad de Medicina Universidad Nacional de Colombia. http://www.revmed.unal.edu.co/revistasp/v1n1/v1n1a2.htm

[19] Romero, Y. (2006) Hábitos que influyen en el proceso salud-enfermedad bucal. Estudio Etnográfico en grupo de madres de la comunidad de San Isidro Estado Mérida, 2003 (Segunda parte). Rev. Acta Odontológica Venezolana, 44.

[20] Adriano, P. and Caudillo, T. (1990) Saber popular en población de Cd. Nezahualcoyotl. Facultad de Estudios SuperioresZaragoza UNAM, México. 
Scientific Research Publishing (SCIRP) is one of the largest Open Access journal publishers. It is currently publishing more than 200 open access, online, peer-reviewed journals covering a wide range of academic disciplines. SCIRP serves the worldwide academic communities and contributes to the progress and application of science with its publication.

Other selected journals from SCIRP are listed as below. Submit your manuscript to us via either submit@scirp.org or Online Submission Portal.
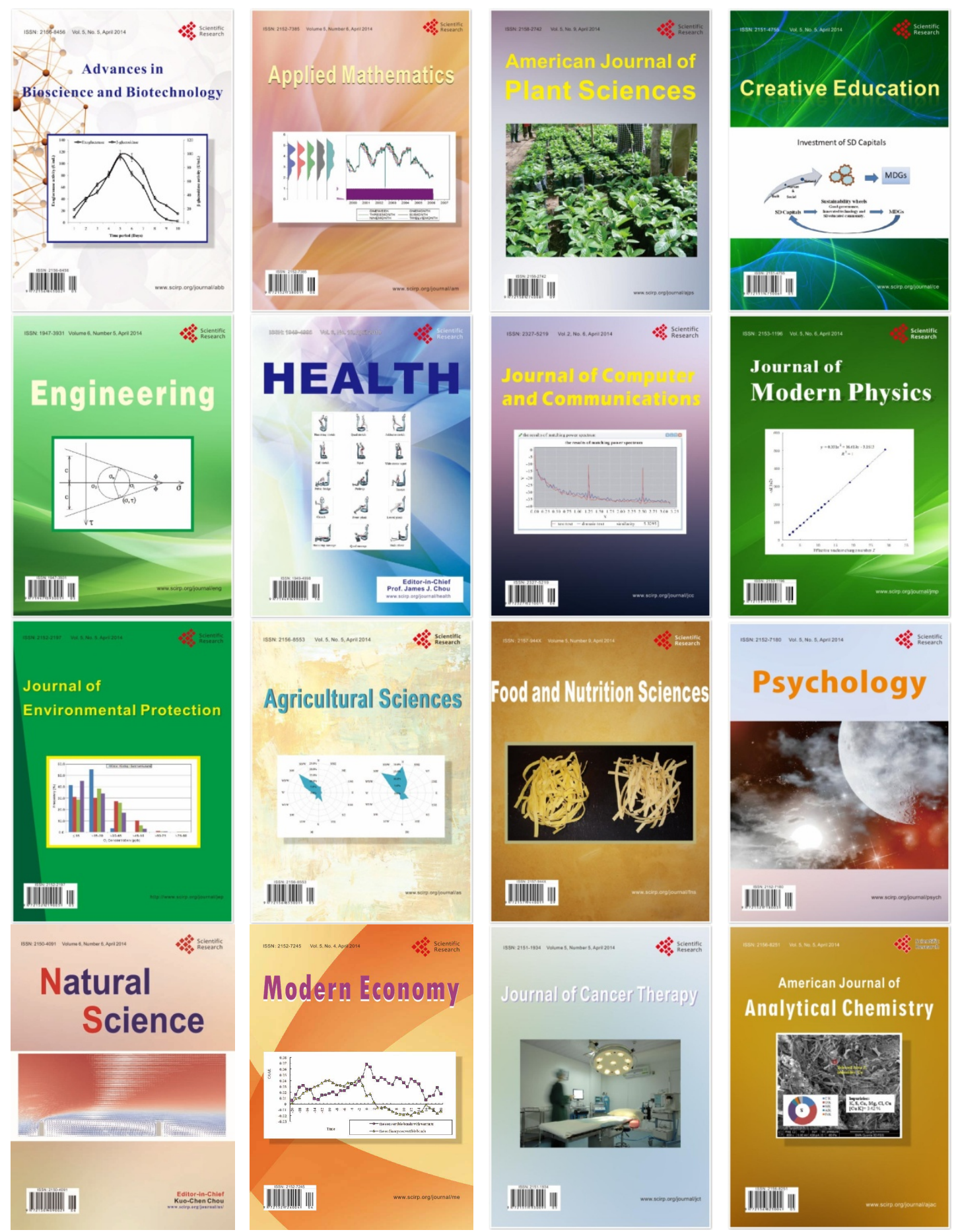